\title{
The Role of Enterprise Risk Management as a Moderation in Increasing Company Value
}

\author{
Fia Fauzia Burhanuddin 1 \\ Student in the Magister of Accounting \\ Faculty of Economic and Business \\ Hasanuddin University, Makassar, Indonesia
}

\begin{abstract}
We try to explain the role of enterprise risk management as a moderation in increasing firm value (empirical study on manufacturing companies that have been listed on the Indonesia Stock Exchange (IDX) for the period of 2016-2018. in this study are manufacturing companies listed on the Indonesia Stock Exchange (BEI) during the period 2016 to 2018. Samples using the purposive sampling method, there are 14 companies as samples. The analytical tool used is multiple linear regression analysis with Moderated Regression Analysis (MRA) which aims to analyze the influence of corporate social responsibility (CSR), managerial ownership, independent commissioners and audit committees on firm value with enterprise risk management as a moderating variable using SPSS v.22 software The results of the study show evidence that: (1) Corporate social responsibility sponsibility has a positive and significant effect on firm value. (2) Managerial ownership has a positive and significant effect on firm value. (3) Independent commissioners have a positive and significant effect on company value. (4) The audit committee has a positive and significant effect on the value of the company. (5) Enterprise risk management is able to moderate the influence of corporate social responsibility on corporate value. (6) Enterprise risk management is able to moderate the influence of managerial ownership on firm value. (7) Enterprise risk management is able to moderate the influence of independent commissioners on company value. (8) Enterprise risk management is able to moderate the influence of the audit committee on the company's value.
\end{abstract}

Keywords:- Corporate Social Responsibility, Managerial Ownership, Independent Commissioners, Audit Committee, Company Value, Enterprise Risk Management.

\section{INTRODUCTION}

Research on the influence of corporate governance mechanisms has been carried out, among others by [11] where the results show that corporate governance mechanisms affect corporate value. Research [10] examines the effect of corporate governance mechanisms on earnings quality and firm value. The results of his study showed a significant influence between the mechanisms of corporate governance and corporate value. [7] research examines the effect of corporate governance and financial leverage on the value of American companies. The results showed a significant effect.

\author{
Gagaring Pagalung2 and R.A Damayanti3 \\ Department of Accounting \\ Faculty of Economic and Business \\ Hasanuddin University, Makassar, Indonesia
}

[8] examined the effect of corporate governance on firm value. The results of this study are consistent with agency theory which shows that managerial ownership has a significant positive effect on firm value, institutional ownership has a positive and not significant effect on firm value, audit committee has a positive and not significant effect on firm value, the proportion of independent directors has a significant positive effect on firm value, external auditor has a positive and not significant effect on firm value.

Some previous studies revealed that one study with another study did not have consistent or conflicting results. [5] and [2] found a positive relationship between firm value and ERM usage. [1] and [6] states that there is a positive interaction between CSR and corporate value. With that it can be said that a superior CSR will get a better company value. Whereas research conducted by [3] found that Corporate Social Responsibility does not significantly influence company value, and risk management moderates managerial ownership, institutional ownership, independent commissioners, and audit committees while risk management does not moderate Corporate Social Responsibility. But the results of [4] research found that there was a significant influence between managerial ownership, institutional ownership, independent commissioners, and audit committees with firm value. This study provides evidence that ERM mediates the influence between institutional ownership, independent commissioners, and audit committees on firm value. But it is not significant in mediating the effect of managerial ownership. Research conducted by [6] found that managerial ownership significantly influences firm value, and enterprise risk management (ERM) strengthens the effect of managerial ownership on firm value

This research was motivated because of the inconsistency of the results of previous studies. Therefore, in this study, researchers are interested in conducting further research on "The Role of Enterprise Risk Management as a Moderation in Increasing Compant Value (Empirical Study on Registered Manufacturing Companies on the Indonesia Stock Exchange (IDX) Period 20162018". 
Research aims:

$>$ To determine the effect of corporate social responsibility on company value.

$>$ To determine the effect of managerial ownership on firm value.

To find out the influence of independent commissioners on company value.

To determine the effect of the audit committee on the company's value.

To determine the effect of corporate social responsibility on company value with enterprise risk management as a moderating variable.

$>$ To determine the effect of managerial ownership on firm value with enterprise risk management as a moderating variable.

$>$ To determine the effect of independent commissioners on the value of the company with enterprise risk management as a moderating variable.

To determine the effect of the audit committee on firm value with enterprise risk management as a moderating variable.

\section{RESEARCH METHOD}

This research uses a quantitative approach with descriptive methods. While based on the level of exploration, this research is classified as associative research. Associative research is research that aims to determine the effect or causal relationship, namely the independent or independent variable $(\mathrm{X})$ on the dependent or dependent variable (Y) [2].

The population in this study are manufacturing companies listed on the Indonesia Stock Exchange (BEI) during the period of 2016 to 2018. And the sample of this study uses a purposive sampling technique, so there are as many as 14 companies that meet the criteria.

The study uses a form of data collection or crosssectional design, which is a type of research conducted by collecting data at the same time for a period of days, weeks or months or years. The type of data used is the type of quantitative data.

The data referred to in this study are earnings per share, dividends per share, and stock prices. The source of data in this study is secondary data obtained from institutions or agencies related to the object of research and obtained through documents, namely data from the 20162018 Published Financial Reports published by the Indonesia Stock Exchange. The data collection technique used is the documentation technique, which is a technique carried out by collecting, recording, and reviewing secondary data in the form of financial statements of manufacturing companies listed on the Indonesia Stock Exchange through www.idx.co.id.

\section{RESULTS AND DISCUSSION}

\section{* Research result}

A. Normality Test

To find out whether the data distribution values obtained from the results of the study meet the requirements or not and whether the terms of the regression equation are met, normality requirements will be presented, then chart guidelines are used from the normal probability plot shown in Figures 1 and 2 following:

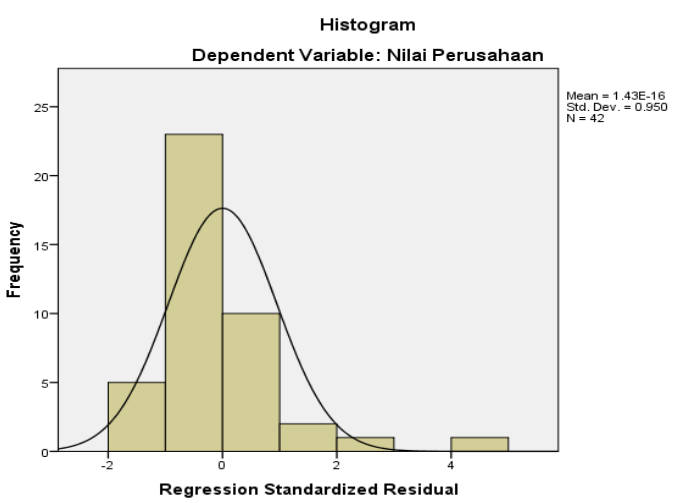

Fig 1:- Histogram

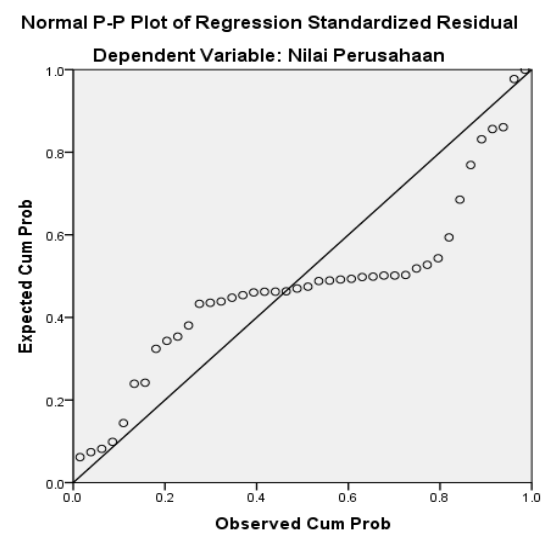

Fig 2:- Normal Probability Plot

Based on the normal probability plot, it can be stated that the data distribution values (see dots) are located around the straight line (not scattered far from the straight line), so it is said that the normality requirements are met meaning that the data collected has met the requirements for publication.

\section{B. Multicollinearity Test}

Based on the results of data processing (appendix 8), it can be explained that multicollinearity testing is used to test a model of whether there is a perfect or almost perfect relationship between independent variables, making it difficult to separate the effect of those variables individually on the dependent variable. This test is to find out whether the independent variables in the regression equation do not correlate with each other. To detect multicollinearity is to look at the value of tolerance and the value of Variance Inflation Factor (VIF), as follows: 


\begin{tabular}{|c|c|c|c|}
\hline \multicolumn{2}{|c|}{ Model } & \multicolumn{2}{c|}{ Collinearity Statistics } \\
\cline { 3 - 4 } & Tolerance & VIF \\
\hline \multirow{7}{*}{1} & (Constant) & & 1.202 \\
\cline { 2 - 4 } & CSR & .832 & 1.101 \\
\cline { 2 - 4 } & $\begin{array}{c}\text { Managerial } \\
\text { ownership }\end{array}$ & .908 & 1.151 \\
\cline { 2 - 4 } & $\begin{array}{c}\text { Independent } \\
\text { Commission }\end{array}$ & .869 & 1.157 \\
\cline { 2 - 4 } & $\begin{array}{c}\text { Audit } \\
\text { Committee }\end{array}$ & .864 & \\
\hline
\end{tabular}

a. Dependent Variable: Company Value.

Table 1:- Coefficients

To detect the presence of multicollinearity is to use the value of tolerance and the value of Variance Inflation Factor (VIF). If the tolerance value is not less than 0.1 and the value of the variance inflation factor is smaller than 10 , then there is no multicollinearity in the model. Based on table 1 , it can be explained that there is no multicollinearity.

\section{Heteroscedasticity Test}

Next, to find out whether the regression model is free from heteroscedasticity, a heteroscedasticity test is used by using scatterplot by observing the picture as follows:

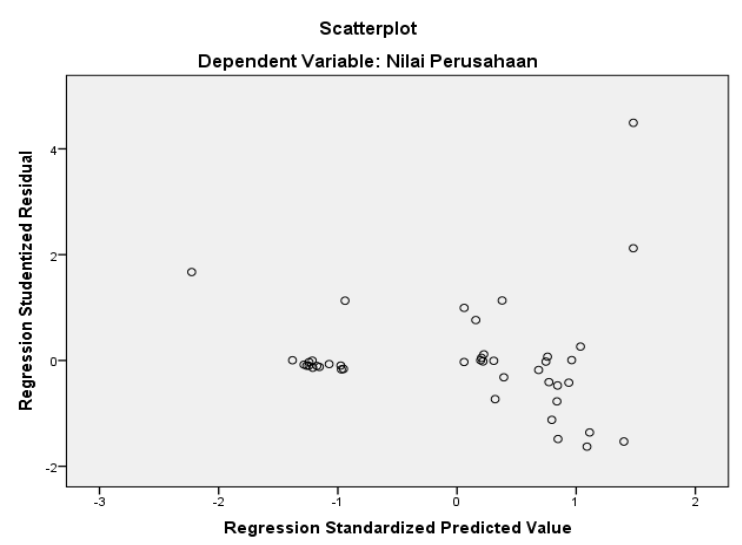

Fig 3:- Scatterplot of Company Value

Based on the scatterplot above, it can be explained that the scattering of data does not appear to show a certain pattern, for example the pattern ascends to the upper right, or decreases to the upper left or certain other patterns. This shows a regression model free from.

\section{Autocorrelation Test}

A good regression model is regression free from autocorrelation. One method that can be used to detect the presence or absence of autocorrelation symptoms is to do the Durbin-Watson (DW) test. Based on the results of research and calculations obtained Durbin-Watson (DW) of 1,352 , while the values of $\mathrm{dL}$ and $\mathrm{dU}$ are $1.3064-1.7202$ (Appendix 9 of the Durbin-Watson (DW) table, $\alpha=5 \%$ ). When the Durbin-Watson (DW) value between $\mathrm{dL}$ and $\mathrm{dU}$, this shows that in the regression model there is no positive or negative autocorrelation so that no autocorrelation occurs.

\section{DISCUSSION OF MODEL}

\section{A. Data Analysis}

Model analysis and hypothesis testing are performed to determine the extent to which the results of statistical tests determine whether or not a hypothesis is accepted. The model used in this study is the Multiple Linear Regression Analysis Model. This model is used to test the effect of corporate social responsibility (X1), managerial ownership (X2), independent commissioners (X3) and audit committee (X4), on the value of the company (Y) both simultaneously / simultaneously and individually / partially.

The results of the calculation of multiple linear regression analysis using SPSS version 22 are presented in the following table.

\begin{tabular}{|c|c|c|c|c||}
\hline \multicolumn{4}{|c|}{} & \multicolumn{4}{|c||}{ Coefficients $^{\mathrm{a}}$} \\
\hline \multirow{2}{*}{ Model } & $\begin{array}{c}\text { Unstandardized } \\
\text { Coefficients }\end{array}$ & $\begin{array}{c}\text { Standardized } \\
\text { Coefficients }\end{array}$ \\
\cline { 2 - 5 } & $\mathbf{B}$ & $\begin{array}{c}\text { Std. } \\
\text { Error }\end{array}$ & Beta \\
\hline \multirow{1}{*}{1} & (Constant) & -2.168 & .798 & .396 \\
\cline { 2 - 5 } & CSR & 2.333 & .894 & .397 \\
\cline { 2 - 5 } & $\begin{array}{c}\text { Managerial } \\
\text { ownership }\end{array}$ & 1.134 & .702 & .365 \\
\cline { 2 - 5 } & $\begin{array}{c}\text { Independent } \\
\text { Commission }\end{array}$ & 3.140 & 1.277 & .192 \\
\hline & $\begin{array}{c}\text { Audit } \\
\text { Committee }\end{array}$ & .325 & .252 & \\
\hline \multicolumn{3}{|c|}{ a. Dependent Variable: Company Value } \\
\hline
\end{tabular}

Table 2:- Summary of Results of Multiple Linear Regression Analysis

In accordance with the results in the table above, the multiple linear regression equation model can be made for this study as follows:

$Y=-2,168+2,333 X_{1}+1,134 X_{2}+3,140 X_{3}+0,325 X_{4}+$ $e(1)$

The equation above shows that:

$>$ Value of constants $=-2,168$; it means that by assuming the independent variable is constant, the value of the company will decrease by 2,168 units;

$>$ If there is an increase in the value of corporate social responsibility $(\mathrm{X} 1)$ by 1 unit, it will increase the value of the company by 2,333 units assuming other variables are fixed..

$>$ If there is an increase in the value of managerial ownership (X2) of 1 unit, it will increase the value of the company by 1,134 units assuming other variables are fixed.

$>$ If there is an increase in the value of an independent commissioner (X3) of 1 unit, it will increase the value of the company by 3,140 units assuming other variables remain.

$>$ If there is an increase in the value of the audit committee (X4) by 1 unit, it will increase the value of the company by 0.325 units assuming other variables remain. 
The magnitude of the relationship and influence between variables can be known by looking at the correlation coefficient (R). Based on the calculation results in the appendix, the results of the correlation coefficient and determination can be presented in the following table.

\begin{tabular}{|c|c|c|c|c|c|}
\hline \multicolumn{5}{|c|}{ Model Summary $^{\mathrm{b}}$} & \\
\hline Model & $\mathbf{R}$ & Square & $\begin{array}{c}\text { Adjusted } \\
\text { R Square }\end{array}$ & $\begin{array}{c}\text { Std. Error } \\
\text { of the } \\
\text { Estimate }\end{array}$ & $\begin{array}{c}\text { Durbin- } \\
\text { Watson }\end{array}$ \\
\hline 1 & $.791^{\mathrm{a}}$ & .626 & .616 & .37166 & 1.352 \\
\hline
\end{tabular}

a. Predictors: (Constant), Audit Committee, Managerial Ownership, Independent Commission, CSR

b. Dependent Variable: Company Value

Table 3:- Summary of Correlation and Determination Coefficient Analysis Results

From this table it can be seen that the value of $\mathrm{R}=$ 0.791. This result means that the relationship between the variables of corporate social responsibility, managerial ownership, independent commissioners and audit committees, with firm values is positive and close.

Value of R2 $=0.626$. This means that $62.6 \%$ of the variation in the ups and downs of the company's value is determined or influenced by corporate social responsibility, managerial ownership, independent commissioners and audit committees. While the remaining $37.4 \%$ is influenced by other variables not examined or not included in this model.

\section{B. Partial Testing ( $t$-Test)}

Partial testing (t-test) is used to test the effect of independent variables on the dependent variable partially or individually, and can also be used to see the influence of the most dominant independent variable. Technically the test is done by comparing the t-counts with the t-value at the significance level $\alpha=0.05$. Based on the calculation results in the appendix, the partial test results (t-test) can be presented in the following table.

\begin{tabular}{|c|c|c|c|c|}
\hline No. & Variable & $\begin{array}{c}\text { Value } \\
\mathbf{t}_{\text {count }}\end{array}$ & Sig. & Conclusion \\
\hline 1. & $\bar{C} \operatorname{CSR}\left(\mathrm{X}_{1}\right)$ & 2,610 & 0,013 & Significant \\
\hline 2. & $\begin{array}{c}\text { Managerial } \\
\text { Ownership (X2) }\end{array}$ & 2,665 & 0,010 & Significant \\
\hline 3 & $\begin{array}{c}\text { Independent } \\
\text { Commission (X3) }\end{array}$ & 2,459 & 0,019 & Significant \\
\hline 4 & $\begin{array}{l}\text { Audit Committee } \\
\text { (X4) }\end{array}$ & 2,289 & 0,005 & Significant \\
\hline & \multicolumn{4}{|c|}{ 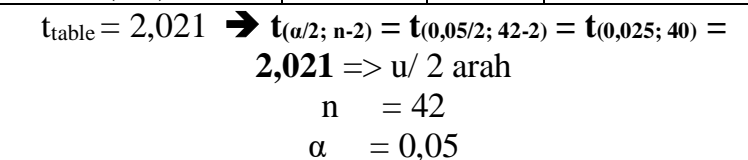 } \\
\hline
\end{tabular}

Table 4:- Partial Test Results (t-Test)

Source: Primary data processed, 2020.
Partial test results (t-tests) summarized in the table above can be explained as follows:

$>$ The t-value of the corporate social responsibility variable $(\mathrm{X} 1)$ is greater than the t-table value (2.610> 2.021) and the significance value (sig.) Is smaller than required $(0.013<0.05)$. These results indicate that corporate social responsibility has a positive and significant effect on firm value (the first hypothesis is proven or accepted).

The t-value of the managerial ownership variable (X2) is greater than the $t$-table value $(2.665>2.021)$ and the significance value (sig.) Is smaller than required $(0.010$ $<0.05)$. These results indicate that managerial ownership has a positive and significant effect on firm value (the second hypothesis is proven or accepted).

$>$ The $\mathrm{t}$-count value of the independent commission variable (X3) is greater than the t-table value (2.459> 2.021) and the significance value (sig.) Is smaller than required $(0.019<0.05)$. These results indicate that corporate social responsibility has a positive and significant effect on firm value (the third hypothesis is proven or accepted).

$>$ The t-count value of the audit committee variable (X4), is greater than the $t$-table value $(2.228>2.021)$ and the significance value (sig.) Is smaller than required $(0.005$ <0.05). These results indicate that managerial ownership has a positive and significant effect on firm value (the fourth hypothesis is proven or accepted).

The criterion in determining the dominant variable refers to the variable that has a greater tcount than the other variables in this study. Based on this, the work managerial ownership variable (X2) has a t-value that is more than the other variables, which is equal to 2.665 . This means that managerial ownership is the most dominant factor affecting the value of the company.

\section{Simultaneous Testing (F-Test)}

Simultaneous testing (F-Test) is used to test the significance of the influence of the independent variables on the dependent variable. The testing technique is done by comparing the value of Fcalculate with the value of Ftable at a significance level of 0.05 and a level of confidence of $95 \%$. Based on the calculation results in the appendix, the partial test results (t-test) can be presented in the following table.

\begin{tabular}{|c|c|c|c|c|c|c|}
\hline \multicolumn{7}{|c|}{ ANOVA $^{\mathrm{a}}$} \\
\hline \multirow{2}{*}{1} & $\begin{array}{c}\text { Sum of } \\
\text { Squares }\end{array}$ & Df & $\begin{array}{c}\text { Mean } \\
\text { Square }\end{array}$ & F & Sig. \\
\hline \multirow{2}{*}{1} & Regression & 4.993 & 4 & 1.248 & 3.820 & $.011^{\mathrm{b}}$ \\
\cline { 2 - 8 } & Residual & 12.091 & 37 & .327 & & \\
\cline { 2 - 8 } & Total & 17.085 & 41 & & & \\
\hline
\end{tabular}

a. Dependent Variable: Company Value

b. Predictors: (Constant), Audit Committees, Managerial Ownership, Independent Commissioners, CSR.

Table 5:- Simultaneous Test Results (F-Test) 
In connection with the results of the calculation of multiple linear regression analysis presented in the table above, it can be seen that the Fcount value is greater than the Ftable value (3.820> 2.63), and the significance value of the count $(\mathrm{sig})=0.011$ which is smaller than the value of $\alpha=0.5$. This result proves that simultaneously or together variables of corporate social responsibility (X1), managerial ownership (X2), independent commissioners (X3) and audit committees (X4) have a significant influence on firm value $(\mathrm{Y})$.

\section{DISCUSSION OF MODEL II}

\section{A. Data Analysis}

Model analysis and hypothesis testing are performed to determine the extent to which the results of statistical tests determine whether or not a hypothesis is accepted. The model used in this study is the Multiple Linear Regression Analysis Model. This model is used to test the effect of corporate social responsibility (X1), managerial ownership (X2), independent commissioners (X3), audit committee (X4), on firm value (Y) and Enterprise Risk Management $(\mathrm{Z})$ as moderating variables.

The results of the calculation of multiple linear regression analysis using SPSS version 22 are presented in the following table.

\begin{tabular}{|c|c|c|c|c|}
\hline \multicolumn{5}{|c|}{ Coefficients $^{\mathrm{a}}$} \\
\hline \multirow{2}{*}{\multicolumn{2}{|c|}{ Model }} & \multicolumn{2}{|c|}{$\begin{array}{l}\text { Unstandardized } \\
\text { Coefficients }\end{array}$} & \multirow{2}{*}{\begin{tabular}{|c|}
$\begin{array}{c}\text { Standardized } \\
\text { Coefficients }\end{array}$ \\
Beta \\
\end{tabular}} \\
\hline & & $\mathrm{B}$ & Std. Error & \\
\hline \multirow[t]{9}{*}{1} & (Constant) & $\begin{array}{c}- \\
1463470.165\end{array}$ & 5933612.366 & \\
\hline & CSR & 3035.792 & 1388.177 & .516 \\
\hline & $\begin{array}{c}\text { Manajerial } \\
\text { ownership }\end{array}$ & .070 & .152 & .161 \\
\hline & $\begin{array}{l}\text { Independent } \\
\text { Commission }\end{array}$ & 2819.259 & 1639.870 & .720 \\
\hline & $\begin{array}{c}\text { Audit } \\
\text { Committee }\end{array}$ & 56090.586 & 236911.681 & .838 \\
\hline & $\mathrm{X} 1 * \mathrm{Z}$ & .370 & .252 & .481 \\
\hline & $\mathrm{X} 2 * \mathrm{Z}$ & .003 & .041 & .027 \\
\hline & $\mathrm{X} 3 * \mathrm{Z}$ & .475 & .469 & .443 \\
\hline & $\mathrm{X} 4 * \mathrm{Z}$ & 13.274 & 54.698 & .869 \\
\hline & a. Dep & t Variabl & ompany $\mathrm{V}$ & \\
\hline
\end{tabular}

Table 6:- Summary of Results of Multiple Linear Regression Analysis

In accordance with the results in the table above, the multiple linear regression equation model can be made for this study as follows:

$Y=-14634470,165+33035,792 X_{1}+0,070 X_{2}+2819,259 X_{3}$ $+56090,586 X_{4}+0,370 X_{1} * Z+0,003 X_{2} * Z+0,475 X_{3} * Z+$ $13,274 X_{4} * Z+e(2)$

The above equation shows that:

Constant value $=-14634470,165$; it means that by assuming constant independent variables, the value of the company will decrease by 14634470.165 units;
If there is an increase in the value of corporate social responsibility $(\mathrm{X} 1)$ by 1 unit, it will increase the value of the company by 33035.792 units assuming other variables remain.

$>$ If there is an increase in the value of managerial ownership (X2) of 1 unit, it will increase the value of the company by 0.070 units assuming the other variables remain.

$>$ If there is an increase in the value of an independent commissioner (X3) of 1 unit, it will increase the value of the company by 2819,259 units assuming other variables remain.

$>$ If there is an increase in the value of the audit committee (X4) by 1 unit, it will increase the value of the company by 56090,586 units assuming other variables remain.

$>$ If there is an increase in the value of corporate social responsibility moderated by enterprise risk management $(\mathrm{X} 1 * \mathrm{Z})$ by 1 unit, it will increase the value of the company by 0.370 units assuming other variables remain.

$>$ If there is an increase in the value of managerial ownership moderated by enterprise risk management $(\mathrm{X} 2 * \mathrm{Z})$ by 1 unit, it will increase the value of the company by 0.003 units assuming other variables remain.

$>$ BIf an increase in the value of independent commissioners is moderated by enterprise risk management $(\mathrm{X} 3 * \mathrm{Z})$ by 1 unit, it will increase the value of the company by 0.475 units assuming other variables remain.

$>$ If there is an increase in the value of the audit committee moderated by enterprise risk management $(\mathrm{X} 4 * \mathrm{Z})$ by 1 unit, it will increase the value of the company by 13,274 units assuming other variables remain.

The magnitude of the relationship and influence between variables can be known by looking at the correlation coefficient (R). Based on the calculation results in the appendix, the results of the correlation coefficient and determinant can be presented in the following table.

\begin{tabular}{|c|c|c|c|c|}
\hline \multicolumn{5}{|c|}{ Model Summary } \\
\hline Model & R & $\begin{array}{c}\text { R } \\
\text { Square }\end{array}$ & $\begin{array}{c}\text { Adjusted } \\
\text { R Square }\end{array}$ & $\begin{array}{c}\text { Std. Error of the } \\
\text { Estimate }\end{array}$ \\
\hline 1 & $.723^{\mathrm{a}}$ & .523 & .297 & 6125282.33345 \\
\hline
\end{tabular}

a. Predictors: (Constant), X4* Z, Managerial Ownership, $\mathrm{X} 3 * \mathrm{Z}, \mathrm{CSR}, \mathrm{X} 1 * \mathrm{Z}, \mathrm{X} 2 * \mathrm{Z}$, Commission Independent, Audit Committee

b. Dependent Variable: Company Value.

Table 7:- Summary of Correlation and Determination Coefficient Analysis Results

From this table it can be seen that the value of $\mathrm{R}=$ 0.723 . This result means that the relationship between the variables of corporate social responsibility, managerial ownership, independent commissioners and audit committees, enterprise risk management and firm value is positive and close. 
Value of $\mathrm{R} 2=0.523$. This means that $52.3 \%$ of the variation in the ups and downs of the company's value is determined or influenced by corporate social responsibility, managerial ownership, independent commissioners and audit committees and enterprise risk management. While the remaining $47.7 \%$ is influenced by other variables not examined or not included in this model.

\section{B. Partial Testing ( $t$-Test)}

Partial testing (t-test) is used to test the effect of independent variables on the dependent variable partially or individually, and can also be used to see the influence of the most dominant independent variable. Technically the test is done by comparing the value of tcount with the value of ttable at the significance level $\alpha=0.05$. Based on the calculation results in the appendix, the partial test results (ttest) can be presented in the following table.

\begin{tabular}{|c|c|c|c|c|}
\hline No. & Variable & $\begin{array}{c}\text { Value } \\
\text { t }_{\text {count }}\end{array}$ & Sig. & Conclusion \\
\hline 1. & $\overline{C S R}\left(X_{1}\right)$ & 2,187 & 0,036 & Significant \\
\hline 2. & $\begin{array}{l}\text { Managerial } \\
\text { Ownership } \\
(\mathrm{X} 2)\end{array}$ & 3,012 & 0,047 & Significant \\
\hline 3 & $\begin{array}{l}\text { Independent } \\
\text { Commission } \\
\text { (X3) }\end{array}$ & 3,719 & 0,015 & Significant \\
\hline 4 & $\begin{array}{c}\text { Audit } \\
\text { Committee } \\
(\mathrm{X} 4)\end{array}$ & 4,237 & 0,014 & Significant \\
\hline 5 & $\mathrm{X}_{1} * \mathrm{Z}$ & 2,469 & 0,001 & Significant \\
\hline 6 & $\mathrm{X}_{2} * \mathrm{Z}$ & 3,080 & 0,007 & Significant \\
\hline 7 & $\mathrm{X}_{3} * \mathrm{Z}$ & 3,014 & 0,018 & Significant \\
\hline 8 & $\mathrm{X}_{4} * \mathrm{Z}$ & 2,243 & 0,010 & Significant \\
\hline & \multicolumn{4}{|c|}{$\begin{array}{c}\mathrm{t}_{\text {table }}=2,021 \rightarrow \mathbf{t}_{(\boldsymbol{\alpha} / \mathbf{2} ; \mathbf{n}-\mathbf{2})}=\mathbf{t}_{(\mathbf{0 , 0 5} / \mathbf{2} ; \mathbf{4 2 - 2})}=\mathbf{t}_{(\mathbf{0}, \mathbf{0 2 5} ; \mathbf{4 0 )}=}= \\
\mathbf{2 , 0 2 1}=>\mathrm{u} / 2 \operatorname{arah} \\
\mathrm{n}=42 \\
\alpha \quad=0,05\end{array}$} \\
\hline
\end{tabular}

a. Dependent Variable: Company Value Table 8:- Interaction Test

Partial test results (t-tests) summarized in the table above can be explained as follows:

$>$ The t-value of the corporate social responsibility variable $(\mathrm{X} 1)$ is greater than the t-table value (2.187> 2.021) and the significance value (sig.) Is smaller than required $(0.036<0.05)$. These results indicate that corporate social responsibility has a positive and significant effect on firm value (the first hypothesis is proven or accepted).

$>$ The t-value of the managerial ownership variable (X2) is greater than the t-table value (3.012> 2.021) and the significance value (sig.) Is smaller than required $(0.047$ $<0.05)$. These results indicate that managerial ownership has a positive and significant effect on firm value (the second hypothesis is proven or accepted).

$>$ The t-count value of the independent commissioner variable (X3) is greater than the t-table value $(3,719>$ $2,021)$ and the significance value (sig.) Is smaller than required $(0.015<0.05)$. These results indicate that the independent commission has a positive and significant effect on firm value (the third hypothesis is proven or accepted).

$>$ The t-count value of the audit committee variable (X4), is greater than the $t$-table value $(4.237>2.021)$ and the significance value (sig.) Is smaller than required $(0.014$ $<0.05)$. These results indicate that the audit committee has a positive and significant effect on firm value (the fourth hypothesis is proven or accepted).

$>$ The t-value of the corporate social responsibility variable moderated by enterprise risk management (X1 $* \mathrm{Z})$ is greater than the t-table value $(2,469>2,021)$ and the significance value (sig.) Is smaller than required $(0.001<0.05)$. These results indicate that corporate social responsibility moderated by enterprise risk management has a positive and significant effect on firm value (the fifth hypothesis is proven or accepted).

$>$ The t-value of the managerial ownership variable moderated by enterprise risk management $(\mathrm{X} 2 * \mathrm{Z})$ is greater than the t-table value $(3.080>2.021)$ and the significance value (sig.) Is smaller than required $(0.007$ <0.05). These results indicate that managerial ownership moderated by enterprise risk management has a positive and significant effect on firm value (the sixth hypothesis is proven or accepted).

$>$ The t-value of the independent commission variable moderated by enterprise risk management $(\mathrm{X} 3 * \mathrm{Z})$ is greater than the t-table value $(3.014>2.021)$ and the significance value (sig.) Is smaller than required $(0.018$ $<0.05)$. These results indicate that an independent commission moderated by enterprise risk management has a positive and significant effect on firm value (the seventh hypothesis is proven or accepted).

$>$ The t-count value of the audit committee variable, which is moderated by enterprise risk management (X4 $* \mathrm{Z}$ ), is greater than the t-table value $(2.224>2.021)$ and the significance value (sig.) Is smaller than required $(0.010<0.05)$. These results indicate that the audit committee moderated by enterprise risk management has a positive and significant effect on firm value (the eighth hypothesis is proven or accepted).

The criterion in determining the dominant variable refers to the variable that has a greater tcount than the other variables in this study. Based on this, the audit committee variable $(\mathrm{X} 4)$ has a t-value that is more than the other variables, which is 4.237 . This means that the audit committee variable is the most dominant factor affecting the value of the company.

\section{Simultaneous Testing (F-Test)}

Simultaneous testing (F-Test) is used to test the significance of the influence of the independent variables on the dependent variable. The testing technique is done by comparing the value of Fcalculate with the value of Ftable at a significance level of 0.05 and a level of confidence of $95 \%$. Based on the calculation results in the appendix, the partial test results (t-test) can be presented in the following table. 
ISSN No:-2456-2165

\begin{tabular}{|c|c|c|c|c|c|c|}
\hline \multicolumn{7}{|c|}{$\begin{array}{c}\text { Simultaneous Test Results (F-Test) } \\
\text { ANOVAa }\end{array}$} \\
\hline & Model & Sum of Squares & df & Mean Square & $\mathrm{F}$ & Sig. \\
\hline \multirow[t]{3}{*}{1} & Regression & 465527313045096.700 & 8 & 58190914130637.090 & 5.551 & $.008^{\mathrm{b}}$ \\
\hline & Residual & 1238129760929474.000 & 33 & 37519083664529.540 & & \\
\hline & Total & 1703657073974571.000 & 41 & & & \\
\hline \multicolumn{7}{|c|}{ a. Dependent Variable: Company Value } \\
\hline \multicolumn{7}{|c|}{$\begin{array}{l}\text { b. Predictors: (Constant), X4 } * \text { Z, Managerial Ownership, X3 } * \text { Z, CSR, X1 } * \text { Z, X2 * Z, Independent Commission, Audit } \\
\text { Committee. }\end{array}$} \\
\hline
\end{tabular}

In connection with the results of the calculation of multiple linear regression analysis presented in the table above, it can be seen that the Fcount value is greater than the Ftable value (5.551> 2.23), and the significance value of the count $(\mathrm{sig})=0.008$ which is smaller than the value of $\alpha=0.5$. These results prove that simultaneously or together corporate social responsibility variables (X1), managerial ownership (X2), independent commissioners (X3), audit committees (X4) and enterprise risk management $(\mathrm{Z})$ have a significant influence on firm value (Y ).

\section{CONCLUSION}

Based on the results of the analysis that has been done, the conclusions from this study can be drawn:

$>$ Corporate social responsibility has a positive and significant effect on company value. This research is in line with the theory used, namely signal theory. Disclosure of CSR information can enhance a company's reputation and value. Therefore, the more companies disclose their social activities, the better the company's reputation and image.

$>$ Managerial ownership has a positive and significant effect on firm value. The results of this study indicate that managerial ownership can reduce the mismatch of interests between agents and principals so as to increase the value of the company.

Independent commissioners have a positive and significant effect on company value. This shows that effective monitoring of management carried out by an independent board of commissioners will be able to help minimize agency conflict which will ultimately impact on the company's value.

$>$ The audit committee has a positive and significant effect on the value of the company. The results of this study indicate that the audit committee supports the theory used, namely agency theory that comprehensively explains the conflict of interests between management as an agent and shareholders as the principal, commonly called the agency problem. This is also one indicator that is able to influence the value of the company.

$>$ Enterprise risk management is able to moderate the influence of corporate social responsibility on company value. This occurs because CSR disclosures are open and transparent conducted by managers, and also reports ERM in the company's financial statements properly. This is in line with the signal theory where this theory emphasizes the importance of disclosure of company information that can produce investment decisions from parties outside the company.

$>$ Enterprise risk management is able to moderate the effect of managerial ownership on firm value. That is because the existence of ERM will force management to set a good risk management strategy that prioritizes the achievement of company goals, namely high corporate value.

$>$ Enterprise risk management is able to moderate the influence of independent commissioners on company value. This happens because the supervisory function of the independent commissioner is running optimally, thus encouraging the implementation of good corporate governance.

$>$ Enterprise risk management is able to moderate the influence of the audit committee on the company's value. This happens because the duties of the audit committee as a control of the company's financial performance and reporting carried out by the manager are functioning optimally, so that the manager will report the ERM in the company's financial statements properly and correctly.

\section{REFERENCES}

[1]. Arafat, M. Y., Warokka, A., Abdullah, H. H., dan Septian, R. R. (2012). The Triple Bottom Line Effect on Emerging Market Companies: A Test of Corporate Social Responsibility and Firm Value Relationship. Journal of Southeast Asian Research, Vol. 2012.

[2]. Bertinetti, G.S., Cavezzali, E., dan Gardenal, G. (2013). The effect of the enterprise risk management implementation on the firm value of European companies. Working Paper No. 10, Department of Management, Università Ca'Foscari Venezia.

[3]. Febyani, P. A. (2016). Pengaruh Good Corporate Governance dan Corporate Social Responsibility Terhadap Nilai Perusahaan Dengan Manajemen Risiko Sebagai Variabel Moderating (Studi Empiris pada Perusahaan Pertambangan dan Energi Yang Terdaftar di BEI Pada Tahun 2010-2013). Jurnal Akuntansi Manajerial. ISSN (E): 2502-6704. Vol. 1, No. 2, Juli - Desember 2016: 46-58.

[4]. Handayani, B. D. (2017). Mekanisme Corporate Governance, Enterprise Risk Management, dan Nilai Perusahaan Perbankan. Jurnal Keuangan dan Perbankan, 21(1): 70-81, 2017. 
[5]. Hoyt, R.E. dan Liebenberg, A.P. (2011), "The value of enterprise risk management". Journal of Risk and Insurance, Vol. 78 No. 4, pp. 795-822.

[6]. Hu, Y., Chen, S., Shao, Y., dan Gao, S. (2018). CSR and Firm Value: Evidence From China. Sustainability. Vol.10 (4597).

[7]. Obradovich, J., dan Gill, A. (2013). The Impact of Corporate Governance and Financial Leverage on the Value of American Firms. International Research Journal of Finance and Economics, 91: 1-14.

[8]. Perdana, R. S., dan Raharja. (2014). Analisis Pengaruh Corporate Governance terhadap Nilai Perusahaan. Diponegoro Journal of Accounting, 3(3): $1-13$.

[9]. Rasmini, N. K. (2019). Pengaruh Kepemilikan Manajerial pada Nilai Perusahaan dengan Pengungkapan Enterprise Risk Management Sebagai Variabel Pemoderasi. Matrik : Jurnal Manajemen, Strategi Bisnis dan Kewirausahaan. Vol. 13, No. 2, Agustus 2019.

[10]. Rupilu, W. (2011). Pengaruh Mekanisme Corporate Governance terhadap Kualitas Laba dan Nilai Perusahaan pada Perusahaan Manufaktur yang Terdaftar di Bursa Efek Indonesia. Jurnal Akuntansi, Manajemen Bisnis, dan Sektor Publik, 8(1): 101-127.

[11]. Suyanti, A. N., Rahmawati., dan Aryani, A. Y. (2010). Pengaruh Mekanisme Corporate Governance Terhadap Nilai Perusahaan dengan Kualitas Laba Sebagai Variabel Intervening pada Perusahaan Manufaktur yang Terdaftar di Bursa Efek Indonesia Periode 2004-2007. Jurnal Ekonomi dan Bisnis, 4(3): 173-183.

[12]. Sekaran, U., dan Bougie, R. (2017), Metode Penelitian untuk Bisnis: Pendekatan PengembanganKeahlian, Edisi 6, Buku 2, Jakarta Selatan: Salemba Empat. 